\title{
Development of Molecular Genetic Interventions for HIV Infection
}

This unit includes a set of protocols for the ex vivo transfer of genes into CD4 $4^{+} \mathrm{T}$ cells, to be used in the initial evaluation of genes protecting against HIV infection in gene therapy protocols. An overview of the procedures is provided in Figure 13.6.1. Procedures are described for isolating and expanding $\mathrm{CD}^{+} \mathrm{T}$ cells from the patient (see Basic Protocol), which are then transduced by either retroviral transduction (see Support Protocol 1) or particle-mediated gene transfer (see Support Protocol 2) and reinfused into the patient. To monitor the effectiveness of gene transfer, genomic DNA is prepared from

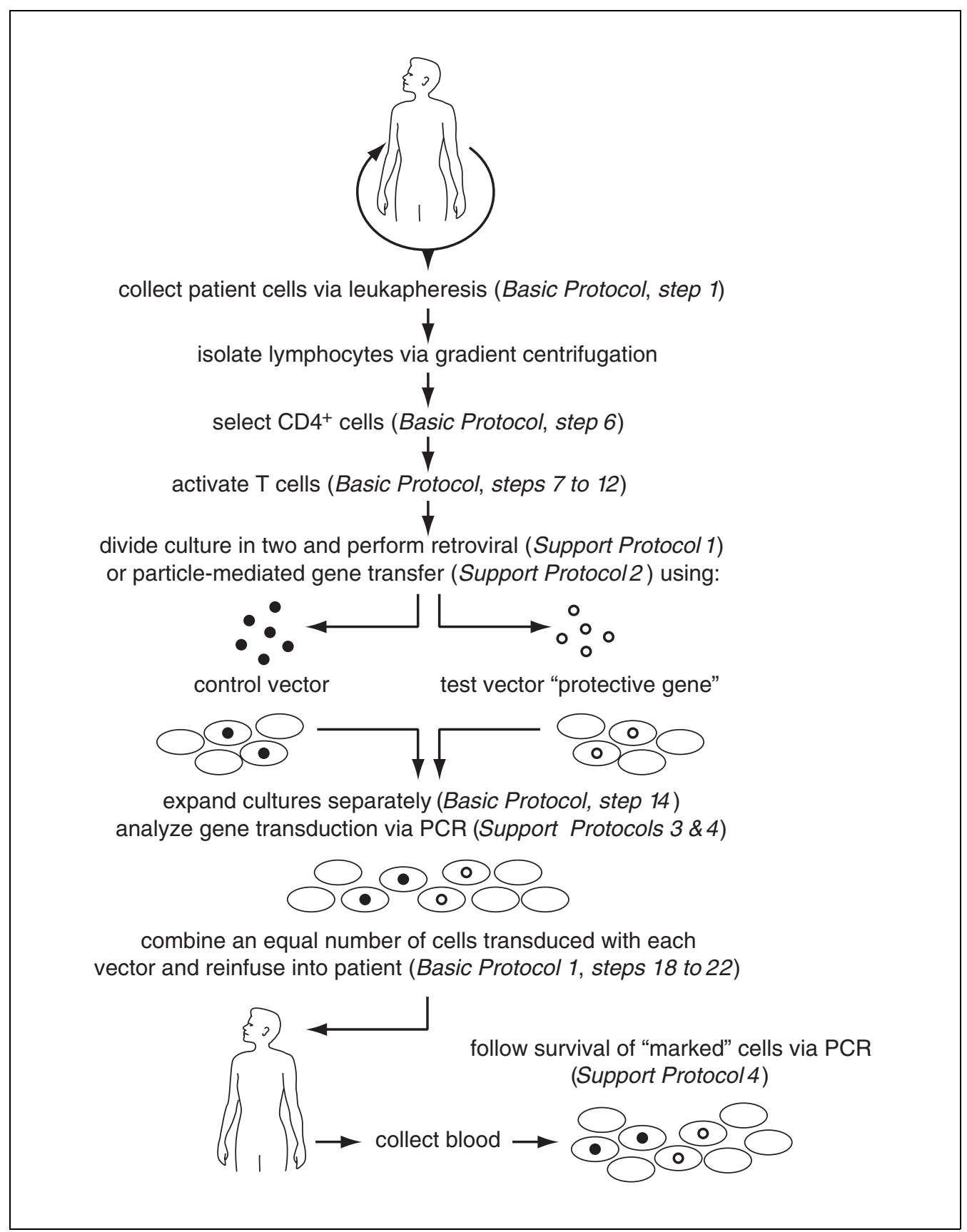

Figure 13.6.1 Overview of ex vivo gene transfer to $\mathrm{CD} 34^{+} \mathrm{T}$ cells. 
the patient's cells (see Support Protocol 3). Detection of vector DNA by PCR analysis of the patient's genomic DNA following gene transfer is also described in detail (see Support Protocol 4).

Design of appropriate DNA constructs is of critical importance, and is beyond the scope of this unit. The methods employed by the authors in their initial HIV gene therapy protocol involve the use of vectors expressing a transdominant negative HIV Rev protein, Rev M10, which has previously been shown to inhibit HIV replication in PBL and T cell lines in vitro (Woffendin et al., 1994, 1996). To ensure the validity of their results regarding the survival of PBL transduced with Rev M10, the authors have constructed a frameshifted negative control by deleting the $5^{\prime}$ ATG codon on the Rev M10 coding sequence. Half of the cells isolated from the patient by leukapheresis are transduced separately with the Rev M10-expressing vector and the other half with the control vector; these two groups of cells are eventually combined together and reinfused back into the patient. The procedures in this unit thus enable the survival of Rev M10-transduced and control cells to be followed in the same individual, and eliminate nonspecific effects that may be unrelated to the possible protective effect of the introduced gene.

Before initiation of any protocol, potential therapeutic genes must be extensively evaluated in in vitro assays for their protective effects against HIV and absence of drawbacks such as adverse effects on $\mathrm{T}$ cell function or potential oncogenicity. Approval has to be obtained from the FDA (Food and Drug Administration) and/or the RAC (Recombinant Advisory Committee) prior to any experimental procedures involving human subjects. Likewise, all retroviral vectors or plasmids used to transduce cells must be produced in approved facilities that follow regulated procedures. Following production, the vectors must undergo numerous FDA-required testing procedures and satisfy other numerous microbiological and pharmacological criteria prior to becoming FDA-approved for use in ex vivo transductions.

It is important to realize, in any procedures involving reinfusion of ex vivo-expanded cells, that all the materials-e.g., plasticware and medium-involved in the procedures must be of the highest quality and FDA-approved for the particular purpose in mind. Solutions should ideally be purchased premade and tested for critical parameters such as sterility and endotoxins by the manufacturer. If necessary, specific chemicals should be of USP grade. The facilities where the procedures are to be performed should be as clean as possible and restricted to persons involved in the projects. If the procedures are to be performed in a BL-3 (Biosafety Level 3) facility, the unit should be entirely dedicated to the patient protocol and thoroughly cleaned and decontaminated between patients. See Poli and Fauci (1993) for a detailed description of a BL-3 facility and the equipment needed to handle HIV-contaminated materials.

BASIC PROTOCOL

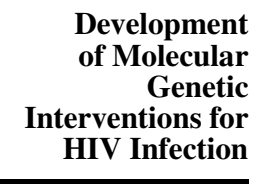

13.6.2

\section{EX VIVO GENE TRANSFER INTO CD4 ${ }^{+}-$ENRICHED T CELLS}

This protocol describes the isolation and activation procedures used to obtain activated $\mathrm{CD} 4^{+}$-enriched T cells (the primary targets for HIV infection) for subsequent transduction and expansion prior to reinfusion into the patient. As the majority of $\mathrm{CD} 4^{+} \mathrm{T}$ cells obtained from patients are quiescent, $\mathrm{T}$ cells must be activated prior to transduction to allow efficient DNA integration after gene delivery. The cells are transduced using a retroviral vector (see Support Protocol 1) or particle-mediated gene transfer is used to introduce a plasmid containing the gene of interest (see Support Protocol 2). Cells are analyzed by PCR both before and after reinfusion into the patient. 


\section{Materials}

Human patient

Histopaque 1077 (Sigma), room temperature

D-PBS (Dulbecco's phosphate-buffered saline without $\mathrm{Mg}^{2+}$ and $\mathrm{Ca}^{2+} ;$ Life Technologies)

$1.33 \mu \mathrm{g} / \mathrm{ml}$ OKT 3 monoclonal antibody (Ortho) in HBSS (APPENDIX 2D) or borate buffer, $\mathrm{pH} 8.6$ (see recipe)

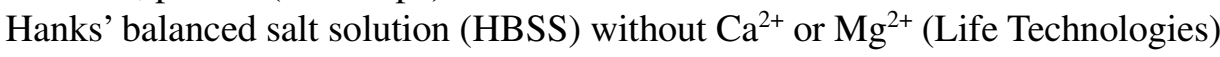

$\mathrm{X}$-Vivo 15 medium containing gentamycin and phenol red (Bio-Whittaker), $37^{\circ} \mathrm{C}$

Delavirdine (Upjohn)

IL-2: aldesleukin (Proleukin from Chiron Therapeutics); reconstitute $2.2 \times 10^{7} \mathrm{IU}$

stock vial with $1.2 \mathrm{ml} \mathrm{H}_{2} \mathrm{O}\left(1.8 \times 10^{7} \mathrm{IU} / \mathrm{ml}\right.$ final; store at $\left.-20^{\circ} \mathrm{C}\right)$

p24 ELISA kit (Coulter)

$25 \%$ human albumin (from hospital pharmacy)

Physiological saline (from hospital pharmacy)

Branched DNA analysis kit (Chiron Therapeutics)

Beckman GPR centrifuge with GH-3.7 rotor (or equivalent) and aerosol containment device

50-ml polypropylene centrifuge tubes

250-ml plug-seal centrifuge tubes

$\mathrm{CD}^{+}$cell selection devices (e.g., CELLector CD8 150-cell culture flasks, Applied ImmuneSciences)

$225-\mathrm{cm}^{2}$ tissue culture flasks

600-ml Fenwal transfer pack (Baxter)

10-ml heparinized blood-collection tubes

10-ml EDTA blood-collection tubes

Additional reagents and equipment for growing cells in tissue culture and counting cells (APPENDIX $3 G$ ) retroviral transduction of cells (see Support Protocol 1) or particle-mediated gene transfer (see Support Protocol 2), preparation of genomic DNA (see Support Protocol 3), and detection of vector DNA by PCR (see Support Protocol 4)

NOTE: All solutions and equipment coming into contact with cells must be sterile, and proper sterile technique should be used accordingly.

NOTE: All culture incubations are performed in a humidified $37^{\circ} \mathrm{C}, 5 \% \mathrm{CO}_{2}$ incubator unless otherwise specified.

CAUTION: All procedures should be performed following standard Biosafety Level 2/Biosafety Level 3 procedures as described in Biosafety in Microbiology and Biomedical Labs (CDC/NIH.HHS publication no. CDC39-8395).

\section{Isolate lymphocytes and enrich for $\mathrm{CD4}^{+}$cells}

1. Obtain PBMC suspension from patient via leukapheresis or similar hospital outpatient procedure.

Leukapheresis is a procedure using a mechanical collection device to efficiently remove large numbers of PBMC's from a subject. Usually $\sim 2-4 \times 10^{9}$ total cells are obtained by leukapheresis in a volume of $\sim 150 \mathrm{ml}$ (the entire procedure takes usually 2 to $3 \mathrm{hr}$ ). A protocol for leukapheresis (also known as lymphapheresis) is found in Strober (1996).

2. Carefully layer 25-ml aliquots of the PBMC cell suspension from the leukapheresis bag on top of 25-ml cushions of Histopaque 1077 in 50-ml polypropylene centrifuge tubes. Keep the 50-ml tubes in aerosol containment vessels inside the hood until they are transferred to the centrifuge.

Six tubes should usually be sufficient. All solutions should be at room temperature.

Delivery Systems for Gene Therapy

\subsection{3}

Supplement 12 
3. Centrifuge the tubes $30 \mathrm{~min}$ at $514 \times g(1500 \mathrm{rpm}$ in a $\mathrm{GH}-3.7$ rotor $), 22^{\circ} \mathrm{C}$, without using a brake.

4. Transfer the tubes to the hood and carefully remove the cloudy interface midway down the tube, which contains lymphocytes including the population of $\mathrm{CD} 4^{+} \mathrm{T}$ cells.

This can be achieved by aspirating off the top layer containing plasma and platelets first and then removing the lymphocytes, or by careful direct pipetting from the interface.

5. Pool the lymphocyte bands in a 250-ml centrifuge tube and wash cells three times, each time by centrifuging $5 \mathrm{~min}$ at $330 \times g(1200 \mathrm{rpm}$ in a GH-3.7 rotor $), 22^{\circ} \mathrm{C}$, removing the supernatant, adding $200 \mathrm{ml}$ D-PBS, then centrifuging again and removing the supernatant.

This step removes any residual Histopaque and the majority of contaminating platelets from the cells.

6. Enrich lymphocyte samples for $\mathrm{CD} 4^{+}$cells using CELLector flasks according to the manufacturer's instructions.

Depending on availability of materials and budget for a particular protocol, many procedures may be used for the enrichment of $\mathrm{CD}^{+}$cells. The authors have been using commercially available FDA-approved plates kindly provided by Applied ImmuneSciences. These devices employ CD8 monoclonal antibody-coated flasks to remove $C D 8^{+}$cells, and thereby enrich for $\mathrm{CD}^{+}$cells. Similar products are available from other companies, as well as magnetic bead and column selection protocols that allow easy enrichment of $C D 4^{+}$ cells by following the manufacturers procedures. Following selection, the proportion of $C D 8^{+}$cells remaining in the peripheral blood lymphocyte population is usually $<10 \%$ as estimated by fluorescence-assisted cell sorting analysis.

\section{Coat flasks with monoclonal antibody for cell activation and activate cells}

7. Coat $225-\mathrm{cm}^{2}$ tissue culture flasks by adding $30 \mathrm{ml}$ of $1.33 \mu \mathrm{g} / \mathrm{ml} \mathrm{OKT} 3$ monoclonal antibody to each and incubating $2 \mathrm{hr}$ at room temperature or at $4{ }^{\circ} \mathrm{C}$ overnight.

Before cells can efficiently be transduced, they must be actively replicating to allow integration of the introduced DNA. Cells that have been enriched for $\mathrm{CD}^{+}$cells are stimulated in flasks coated with monoclonal antibody generated against human CD3 (OKT 3).

Depending on the source of OKT 3, the antibody should be titrated to find the optimal concentration required for activation.

8. Wash the antibody-coated flasks three times, each time with $50 \mathrm{ml}$ D-PBS or HBSS, to remove any unbound antibody.

9. Immediately before transferring to the coated flasks (step 10), resuspend the CD4 ${ }^{+}$ cells in $37^{\circ} \mathrm{C} \mathrm{X}$-Vivo 15 medium at a density of $1-1.5 \times 10^{6}$ cells $/ \mathrm{ml}$. Add Delavirdine to a final concentration of $5 \mu \mathrm{M}$.

Delavirdine is an antiretroviral agent used to inhibit retrovirus replication and reinfection of permissive cells (see Critical Parameters).

10. Pipet $150 \mathrm{ml}$ of $\mathrm{CD}^{+}$cell suspension (containing $100-150 \times 10^{6}$ cells) into each coated flask and incubate 24 to $48 \mathrm{hr}$.

Examine the cells microscopically after 24 hr for signs of activation, such as increase in cell diameter and characteristic clumping. If this is not evident, continue incubation an additional $24 \mathrm{hr}$.

Development of Molecular Genetic Interventions for HIV Infection

13.6.4 
12. Prepare $37^{\circ} \mathrm{C} \mathrm{X}$-Vivo 15 medium containing $50 \mathrm{IU} / \mathrm{ml} \mathrm{IL-2} \mathrm{(added} \mathrm{as} 1.8 \times 10^{7} \mathrm{IU} / \mathrm{ml}$ Proleukin stock) and $5 \mu \mathrm{M}$ Delavirdine. Resuspend activated cells at a density of 3-5 $\times 10^{5}$ cells $/ \mathrm{ml}$ in this medium and transfer to new flasks.

\section{Transduce cells and estimate gene transfer by cell-dilution PCR analysis}

13. Transduce half the activated cells using the Rev M10 test vector and the other half using the frame-shifted negative control vector using either retroviral transfection (see Support Protocol 1) or particle-mediated gene delivery (see Support Protocol 2).

See Critical Parameters for a comparison of the two methods.

14. Continue expanding the cultures for 5 to 10 days to obtain sufficient cells to ensure that the gene transfer frequency will allow detection of the transduced cells once the cells are reinfused and diluted with the patient's own cells.

See Support Protocol 1, step 3, for the expansion procedure. Assuming a 1\% to 10\% transduction frequency, $10^{10}$ cells should be sufficient for detection.

15. Perform serial dilutions of cells (control and test) and prepare genomic DNA (see Support Protocol 3). Perform PCR (see Support Protocol 4) and calculate the approximate percentage of cells transduced with the vectors in the control and test populations.

These analyses should be performed 2 to 3 days post-transduction and again 2 days prior to reinfusion.

The authors' Rev M10 constructs were designed such that PCR of the control vector resulted in a slightly different-sized product that could be distinguished on the gel. Alternatively, if a good specific antibody against the transduced gene product exists, cell transduction can be analyzed by cell staining. If the vector has been designed to coexpress both the gene of the interest and a cell surface-marker, FACS analysis can be used in place of PCR to estimate the level of transfer. Note however that such strategies can result in an immune response in vivo if the marker is immunogenic.

\section{Prepare transduced cells for reinfusion and reinfuse into patient}

16. From the PCR estimations of frequency of transduction for the control and test populations, calculate the number of cells to combine from each group to ensure that the number of transduced cells in each population is approximately equal for purposes of reinfusion.

If cells were transduced by the retroviral transduction method, the transduction frequencies should be very similar if the viral titers for each vector are equivalent in both virus stocks. If the differences are great, the volume of retrovirus-containing supernatants and cells should be adjusted to obtain similar transduction frequencies.

If cells were transduced by the particle-mediated transduction method, the frequency should be similar in each population, assuming the same amount of DNA is used for test and control transductions.

17. Two days prior to reinfusion, send samples for microbiological testing to examine for the presence of anaerobic and aerobic bacteria and fungi. Test cultures for the presence of p24 antigen in the supernatant using the Coulter p24 ELISA kit to ensure that no induction of endogenous HIV has occurred during the expansion protocols.

If p24 levels are above background, the cultures will have to be discarded because of the danger of reintroduction of drug-resistant viruses and/or increase in viral load in the patient.

18. On day of reinfusion, combine all the cells from culture flasks or bags containing test vector-transduced cells in 250-ml centrifuge tubes and all flasks or bags containing 
control vector-transduced cells in separate $250-\mathrm{ml}$ centrifuge tubes and centrifuge $10 \mathrm{~min}$ at $330 \times g(1200 \mathrm{rpm}$ in a GH-3.7 rotor $), 22^{\circ} \mathrm{C}$.

Use the largest centrifuge buckets available, to reduce the time required to process all samples. Alternatively use a cell harvester if one is available.

19. Combine cell pellets from each group and wash at least three times, each time by centrifuging $10 \mathrm{~min}$ at $330 \times g, 22^{\circ} \mathrm{C}$, removing the supernatant, adding $\geq 200 \mathrm{vol}$ D-PBS, then centrifuging again and removing the supernatant. Before the last wash, count cells (APPENDIX $3 G$ ) and calculate from the transduction frequencies (step 15) the number of cells from each group required for reinfusion.

Extensive washing is required to remove cell debris (which is higher in particle-mediated transduction procedures) and any traces of medium or antivirals from the infusion mixture.

Save samples from individual groups separately for FACS and PCR analysis and freeze down aliquots for future analyses.

20. Combine the correct number of cells from each culture and wash one last time as in step 19.

The authors generally try to infuse $\geq 1 \times 10^{10}$ cells per group, and are able to pick up a signal by PCR analysis post-infusion (assuming 1\% to 10\% of the infused cells are transduced).

21. Dilute $25 \%$ human albumin stock solution with physiological saline to a final concentration of $1.25 \%$ and add Proleukin to a final concentration of $1-2.5 \times 10^{5} \mathrm{IU}$ IL-2. Resuspend the final cell pellet in 100 to $250 \mathrm{ml}$ of this solution. Transfer the cell suspension to a $600-\mathrm{ml}$ Fenwal transfer pack using a 50-ml syringe connected to a large-gauge blunt needle.

The needle must be blunt for safety reasons. IL-2 may or may not be needed for the reinfusion; the authors include IL-2 to negate any perturbations that may result in its absence.

22. Reinfuse the transduced cell suspension into the patient by IV infusion over a period of 10 to $15 \mathrm{~min}$ and monitor patient's vital signs for $24 \mathrm{hr}$ for any abnormalities resulting from the infusion procedures.

Ideally, cells should be reinfused within 30 to 60 min of transferring the cells to the infusion bag to avoid any adverse effects from the high concentration of cells.

\section{Perform analysis of patient cells post-infusion}

23. Following reinfusion, take blood samples at intervals from the patient for analysis of the persistence and frequency of the introduced gene. Collect blood from the subject in five to eight 10-ml heparinized blood-collection tubes and isolate lymphocytes by Hypaque gradient centrifugation as described in steps 2 to 5. Collect plasma using two 10-ml EDTA blood collection tubes and analyze for viral load by branched DNA analysis using the Chiron Branched DNA Analysis kit.

Branched DNA analysis is the most accurate and sensitive assay for viral load.

The authors generally take early time-points, e.g., at 1, 4, and $24 \mathrm{hr}$ post-infusion, followed by samples at 1-week and subsequently at 4-week intervals up to 6 months. At all follow-up collection times, blood samples are sent to the clinical laboratory for routine blood work and analysis of CD4/CD8 levels and viral load. Multiple samples of lymphocytes and plasma are always frozen for storage at all time points for possible analysis later.

Development of Molecular Genetic Interventions for HIV Infection

13.6.6 


\section{RETROVIRAL TRANSDUCTION OF CD4 ${ }^{+}$CELLS}

This protocol describes the transduction of enriched $\mathrm{CD}^{+}$lymphocytes with retroviral vectors. It is appropriate for transducing cells with retroviral vectors expressing the gene to be examined for antiviral efficacy, as well as for transducing with a control vector. Retroviral producer lines and virus preparations for in vivo use must be produced in certified laboratories. The methods for production of these stocks is outside the scope of this unit (see UNIT 12.5). The vectors and virus must be FDA-approved and, in addition, vectors should be monitored for replication-competent helper virus using a feline $\mathrm{S}^{+} \mathrm{L}^{-}$ focus assay (a sensitive procedure for detecting a wide variety of xenotropic and amphotropic retroviruses), as well as other virologic assays. The authors have used in their studies a Moloney murine leukemia virus-based vector that expresses Rev M10, as well as the G418 resistance gene, under the control of the SV40 promoter (Nabel et al., 1994). The virus was produced originally by transfecting the Rev M10-expressing plasmid into the $\varphi \mathrm{CRE}$ ecotropic virus packaging cell line; a corresponding procedure was carried out with a control frame-shifted plasmid to produce the control used in the Basic Protocol. Supernatants from this culture were then used to infect the amphotropic $\varphi$ CRIP packaging cell line, which was then selected in G418 for clones with high viral titer. Using this type of procedure, viral supernatants with titers of $1-10 \times 10^{6}$ infectious particles per $\mathrm{ml}$ were obtained.

\section{Materials}

Retrovirus-containing supernatants, test and control (store at $-70^{\circ} \mathrm{C}$; thaw and warm to $37^{\circ} \mathrm{C}$ immediately prior to transduction)

$1 \times 10^{6} \mathrm{cell} / \mathrm{ml}$ suspension of activated $\mathrm{CD}^{+}$lymphocytes (see Basic Protocol, steps 1 to 12 ) and conditioned medium

$10 \mathrm{mg} / \mathrm{ml}$ protamine sulfate stock solution (must be FDA-approved, e.g., Elkins-Sinn)

IL-2: aldesleukin (Proleukin from Chiron Therapeutics); reconstitute $2.2 \times 10^{7} \mathrm{IU}$ stock vial with $1.2 \mathrm{ml} \mathrm{H} \mathrm{H}_{2} \mathrm{O}\left(1.8 \times 10^{7} \mathrm{IU} / \mathrm{ml}\right.$ final; store at $\left.-20^{\circ} \mathrm{C}\right)$

D-PBS (Dulbecco's phosphate-buffered saline without $\mathrm{Mg}^{2+}$ and $\mathrm{Ca}^{2+}$; Life Technologies)

$\mathrm{X}$-Vivo 15 medium containing gentamycin and phenol red (Bio-Whittaker)

Delavirdine (Upjohn)

Beckman GPR centrifuge with GH-3.7 rotor (or equivalent)

3000-ml Fenwal Lifecell tissue culture flasks (Baxter) or equivalent

Additional reagents and equipment for growing cells in tissue culture (APPENDIX $3 G$ )

NOTE: All solutions and equipment coming into contact with cells must be sterile, and proper sterile technique should be used accordingly.

NOTE: All culture incubations are performed in a humidified $37^{\circ} \mathrm{C}, 5 \% \mathrm{CO}_{2}$ incubator unless otherwise specified.

1. Immediately following activation of $\mathrm{CD} 4^{+}$lymphocytes (see Basic Protocol, step 13), incubate cells 4 to $6 \mathrm{hr}$ at a final concentration of $\sim 1 \times 10^{6} \mathrm{cells} / \mathrm{ml}$ with an equal volume of retrovirus-containing supernatant in the presence of $5 \mu \mathrm{g}$ protamine sulfate (added from $10 \mathrm{mg} / \mathrm{ml}$ stock) and $50 \mathrm{IU} / \mathrm{ml} \mathrm{IL-2} \mathrm{(added} \mathrm{from} 1.8 \times 10^{7} \mathrm{IU} / \mathrm{ml}$ Proleukin stock).

The retrovirus is usually produced in DMEM medium.

The amount of retrovirus-containing supernatant required to transduce the cells is dependent on the titer and availability of the virus preparation and the number of cells. Try to use the highest MOI (multiplicity of infection) possible without diluting the cultures too much, as this will lead to multiple centrifugation steps and increase the chances of contamination.
Delivery Systems for Gene Therapy

\subsection{7}

Supplement 12 
SUPPORT PROTOCOL 2

Development of Molecular Genetic Interventions for HIV Infection
To achieve an efficient transduction frequency, viral supernatants should be at titers of at least $1 \times 10^{6} \mathrm{TCID}_{50} \mathrm{ml}$ (as assayed on mouse $3 \mathrm{T3}$ cells), and preferably close to $1 \times 10^{6}$ $T_{C I D} d \mathrm{ml}$. Cells may also be exposed to retroviral vector on 2 consecutive days to increase the transduction frequency. Following transduction, $1 \%$ to $10 \%$ of cells should be transduced.

2. Following transduction, wash cells by centrifuging $10 \mathrm{~min}$ at $330 \times g(1200 \mathrm{rpm}$ in a $\mathrm{GH}-3.7$ rotor), $22^{\circ} \mathrm{C}$, adding $500 \mathrm{ml}$ D-PBS, then centrifuging again and removing the supernatant. Resuspend in fresh X-Vivo 15 medium (ideally containing a proportion of conditioned medium saved prior to the transductions and stored at $37^{\circ} \mathrm{C}$ ) at a concentration of $2-5 \times 10^{5}$ cells/ $\mathrm{ml}$ in Fenwal Lifecell tissue culture flasks in the presence of $50 \mathrm{IU} / \mathrm{ml} \mathrm{IL}-2$ and $5 \mu \mathrm{M}$ Delavirdine.

3. Feed cells with additional X-Vivo 15 medium containing $50 \mathrm{IU} / \mathrm{ml} \mathrm{IL-2} \mathrm{and} 5 \mu \mathrm{M}$ Delavirdine every 2 or 3 days depending on the growth rate of the cells, making sure the cell density remains $<2.0 \times 10^{6}$ cells $/ \mathrm{ml}$.

If culture bags are used, it is helpful to have a portion of each culture growing alongside in a tissue culture flask to allow ready microscopic observation of the cultures to ensure the cells look morphologically healthy and are free of microbial contamination, and (although this is unlikely) that there is no emergence of any viral cytopathic effects resulting from HIV replication.

Continue expanding the culture for 5 to 10 days to obtain a sufficient number of cells to ensure that the gene transfer frequency will allow the detection of the cells once the cells are reinfused and diluted with the patients own cells.

\section{PARTICLE-MEDIATED GENE TRANSFER TO CD4 ${ }^{+}$CELLS}

Particle-mediated gene transfer devices generally employ a helium pulse to deliver gold particles coated with DNA into the cell. The devices were originally developed for gene transfer to plant cells, but have more recently been shown to be highly effective for gene transfer into a wide range of mammalian cell types, including T lymphocytes. DNA is precipitated onto gold particles by precipitation with spermidine and calcium chloride prior to shooting the beads into the cells. Beads of various sizes are available, but in the authors' laboratory gold beads of 1.6- $\mu \mathrm{m}$ diameter have proven most effective.

Various protocols, depending on the manufacturer of the device used, are available for coating DNA to the gold beads and introducing the beads into the cells. Below a protocol is presented that was originally designed by Sanford et al. (1993) and Bio-Rad Laboratories, which the authors have been successfully using in their laboratory with a "gene gun" (Biolistic PDS-1000/He; Bio-Rad). A method using the Agracetus hand-held delivery device (see UNIT 12.6) has also been used effectively in the author's laboratory.

\section{Materials}

1.6- $\mu \mathrm{m}$ gold particles (Bio-Rad)

$70 \%$ and $100 \%$ ethanol

$50 \%(\mathrm{v} / \mathrm{v})$ glycerol

$1 \mathrm{mg} / \mathrm{ml}$ DNA to be transferred (test and control; linearized or supercoiled and gradient purified) in TE buffer or distilled $\mathrm{H}_{2} \mathrm{O}$

$2.5 \mathrm{M} \mathrm{CaCl}_{2}$

$0.1 \mathrm{M}$ spermidine (Sigma)

Activated CD4 ${ }^{+} \mathrm{T}$ lymphocytes (see Basic Protocol, steps 1 to 12) and conditioned medium

Biolistic PDS-1000/He particle-delivery system (Bio-Rad)

Macrocarrier disks for Biolistic PDS-100/He (Bio-Rad) 
Beckman GPR centrifuge with GH 3.7 rotor (or equivalent)

35-mm diameter petri dishes

NOTE: All solutions and equipment coming into contact with cells must be sterile, and proper sterile technique should be used accordingly.

\section{Prepare gold bead stock suspension}

1. Weigh out $60 \mathrm{mg}$ gold particles into a $1.5-\mathrm{ml}$ microcentrifuge tube. Add $1 \mathrm{ml}$ of $70 \%$ ethanol and vortex $2 \mathrm{~min}$, then incubate $15 \mathrm{~min}$ at room temperature.

This quantity will provide sufficient particles for 120 transductions (shots) using $500 \mu \mathrm{g}$ per bombardment. Gold beads are obtained from Bio-Rad in 250-mg lots.

2. Microcentrifuge $5 \mathrm{sec}$ at maximum speed, then remove and discard the supernatant.

3. Add $1 \mathrm{ml}$ sterile water, then vortex $1 \mathrm{~min}$ and let settle $1 \mathrm{~min}$. Microcentrifuge $2 \mathrm{sec}$ at maximum speed, then remove and discard the supernatant. Repeat this washing process two additional times.

4. Add sterile $50 \%$ glycerol to bring final concentration to $60 \mathrm{mg} / \mathrm{ml}$. Store at $4{ }^{\circ} \mathrm{C}$.

\section{Coat DNA onto microcarrier particles}

5. Vortex the gold bead stock suspension for $3 \mathrm{~min}$. For each plasmid to be used (test and control) remove $50 \mu \mathrm{l}$ of gold bead stock suspension and transfer to a separate microcentrifuge tube.

These steps are for six shots; change the volumes depending on the number of shots required.

6. While vortexing add to the bead suspension in the following order:

\section{$5 \mu \mathrm{l} 1 \mu \mathrm{g} / \mathrm{ml} \mathrm{DNA}$ \\ $50 \mu 12.5 \mathrm{M} \mathrm{CaCl}_{2}$ \\ $20 \mu \mathrm{l} 0.1 \mathrm{M}$ spermidine. \\ Vortex $2 \mathrm{~min}$, then allow to settle for $1 \mathrm{~min}$.}

The plasmid DNA used in these procedures can be linearized (outside the protective gene coding region) or supercoiled, although the relative efficacy in generating stable transfectants is not known.

7. Microcentrifuge $5 \mathrm{sec}$ at maximum speed, then remove and discard the supernatant.

8. Wash the beads with $200 \mu 1$ of $70 \%$ ethanol without disturbing the pellet (i.e., by slowly adding the ethanol down the wall of the tube and removing the ethanol by pipetting), then wash with $200 \mu \mathrm{l}$ of $100 \%$ ethanol in the same manner.

9. Add $50 \mu \mathrm{l}$ of $100 \%$ ethanol to the beads and resuspend by vortexing 2 to $5 \mathrm{sec}$.

10. Remove six $8-\mu 1$ aliquots of bead suspension in ethanol and place in the central $\mathrm{cm}^{2}$ of each macrocarrier disk, very quickly to prevent settling and clumping of beads which can reduce the transduction frequency. Dry immediately for $\geq 10 \mathrm{~min}$ in the hood.

\section{Transduce cells}

11. Assemble the Biolistic PDS-1000/He system with the macrocarrier disk containing the beads as described by the manufacturer

A detailed manual outlining the steps required to operate the gene gun is available from the manufacturer and will not be considered in this unit. The interior of the apparatus can be cleaned with $70 \%$ ethanol or glutaldehyde solution (available commercially as Glutarex, Cidex and Sonacide) prior to use; the residual solutions are removed by wiping with sterile gauze.

Delivery Systems for Gene Therapy

\subsection{9}

Supplement 12 
SUPPORT PROTOCOL 3

Development of Molecular Genetic Interventions for HIV Infection

12. Immediately prior to transduction, centrifuge activated $\mathrm{CD} 4^{+}$lymphocytes at $330 \times$ $g\left(1200 \mathrm{rpm}\right.$ in a GH-3.7 rotor), $22^{\circ} \mathrm{C}$, then resuspend at a concentration of $10-20 \times$ $10^{6}$ cells per $100 \mu \mathrm{X}$ X-Vivo 15 medium. Spread $100 \mu \mathrm{l}$ of cell suspension over a $4-\mathrm{cm}^{2}$ central area of a 35-mm diameter petri dish and proceed immediately to transduction (step 13).

It is very important that this step is done quickly to ensure that the cells do not dry out on the plate.

13. Deliver particles as described in Woffendin et al. (1994) with the following modified parameters:

rupture disk macrocarrier gap, $3 / 4$ in

macrocarrier travel distance, $6 \mathrm{~mm}$

chamber vacuum, 15 in. of $\mathrm{Hg}$

helium pressure, 1300 to 1800 psi

target distance, $4 \mathrm{~cm}$.

14. Following transduction, remove cells immediately from the dish by washing with fresh X-Vivo 15 medium, then resuspend at a concentration of $2-5 \times 10^{5}$ cells $/ \mathrm{ml}$ in conditioned medium.

The conditioned medium should contain IL-2 and Delaverdine (see Basic Protocol).

Following shooting, microscopic examination of the petri dish should show numerous cells containing beads and abundant free beads in the background.

15. Expand cultures (see Support Protocol 1, step 3).

\section{SMALL-SCALE PREPARATION OF GENOMIC DNA FROM PERIPHERAL BLOOD LYMPHOCYTES}

Serially diluted peripheral blood lymphocyte (PBL) samples (from transduced cells prior to infusion or from patient-derived cells post-infusion) are incubated with detergents and proteinase $\mathrm{K}$ to lyse the cells and digest the proteins. After heat inactivation of the proteinase $\mathrm{K}$, the lysate may be used directly for PCR or stored at $-20^{\circ} \mathrm{C}$ for future use.

The purpose of the serial dilutions is to enable a quantitative estimate of transduction frequency by PCR (see Support Protocol 4).

CAUTION: PBL may be derived from infected individuals and hence must be handled with due precaution and only in the BSL-2 or BSL-3 facility. Samples can be taken out of this lab only following lysis of cells.

NOTE: Experiments involving PCR require extremely careful technique to prevent contamination and DNA/RNA degradation; see Support Protocol 4 and APPENDIX 2D.

\section{Materials}

PBL from clinical samples (e.g., see Basic Protocol steps 15 and 24) to be analyzed for the presence of transduced DNA

Untransduced PBL from normal HIV-seronegative donor for background DNA

PBS (APPENDIX 2D), sterile

Filler cells: untransduced PBL or any transformed T cell lines-e.g., CEM cells or Jurkat cells

Quick lysis solution A (see recipe)

Quick lysis solution B (see recipe)

Light mineral oil (Sigma)

Aerosol-barrier pipet tips

Heating block

13.6.10 
Additional reagents and equipment for counting cells (APPENDIX $3 G$ )

1. Count the PBL derived from the clinical samples. Perform serial dilution of PBL in sterile PBS, ranging from $1 \times 10^{5}$ cells per $0.5-\mathrm{ml}$ microcentrifuge tube to 1 cell per $0.5 \mathrm{ml}$ microcentrifuge tube, using untransduced PBL, CEM cells, or Jurkat cells as filler cells to keep the cell concentration constant at $1 \times 10^{5}$ cells.

DNA derived from the normal HIV-seronegative donor PBL will serve as background DNA in PCR.

2. Microcentrifuge samples $2 \mathrm{~min}$ at $2000 \mathrm{rpm}, 22^{\circ} \mathrm{C}$. Aspirate supernatants with extreme care (as the cell pellets may not be easily visible) using a fresh aerosol-barrier pipet tip for each sample.

3. Using a fresh aerosol-barrier pipet tip for each sample, add 10 to $20 \mu \mathrm{l}$ quick lysis solution A to each pellet and resuspend thoroughly.

It is very important to avoid sample-to-sample contamination at this step. 10 to $20 \mu \mathrm{l}$ of the quick lysis solution per $10^{5}$ cells is a fair approximation. If more cells are used the solution added must be increased proportionately.

4. Add an equal volume (10 to $20 \mu \mathrm{l}$ ) of solution B (containing proteinase $\mathrm{K}$ ) to each sample and mix.

5. Add 10 to $20 \mu \mathrm{l}$ light mineral oil to each vial. Incubate tubes on a heating block, $1 \mathrm{hr}$ at $56^{\circ} \mathrm{C}$ then $20 \mathrm{~min}$ at $95^{\circ} \mathrm{C}$.

During the first incubation, proteinase $K$ will digest all the protein in the sample; during the second, proteinase $K$ is inactivated so that it will not degrade the Taq DNA polymerase in the subsequent PCR (see Support Protocol 4). Alternatively, samples may be treated with proteinase Kovernight at room temperature or $37^{\circ} \mathrm{C}$.

6. Keep samples on ice if they are to be used immediately or store at $-20^{\circ} \mathrm{C}$ (stable for months).

Additional cleaning of the DNA (e.g., phenol/chloroform extraction and ethanol precipitation) is not necessary for DNA amplification. The detergents present in quick lysis solution $B$, in fact, may enhance the efficiency of the Taq DNA polymerase. Attempts at additional purification may lead to increased chances of false-positive results; hence it is better to avoid such measures.

Genomic DNA from cells stably transduced with the target vectors (see UNIT12.5) may be prepared, following the same protocol, to serve as positive standards in PCR. Prepare a large number of single-use aliquots (11 or $12 \mu \mathrm{l}$ per microcentrifuge tube) of standards composed of cell extracts from dilutions of known cell number (100, 10, 2, 1, or 0 cells) and store at $-20^{\circ} \mathrm{C}$ at which temperature they are stable for months. Note that these must be kept in a different freezer than the one in which clinical DNA is stored.

Delivery Systems for Gene Therapy

\subsubsection{1}

Supplement 12 
SUPPORT PROTOCOL 4

\section{DETECTION OF THE VECTOR DNA BY PCR FOLLOWING EX VIVO GENE TRANSFER TO PERIPHERAL BLOOD LYMPHOCYTES}

Following ex vivo gene transfer, the proportion of the lymphocytes carrying the vector DNA will be very small in the peripheral blood-often in the range of one in $10^{5}$ to $10^{6}$ cells. Techniques such as western blot are not sensitive enough to detect transduced cells at such low frequencies. Amplification of the DNA by PCR, on the other hand is the ideal detection method for this purpose. This protocol describes amplification by PCR and detection of the amplified product.

It should be emphasized here that the process of amplification by PCR is highly prone to false-positive results, especially when the frequency of the target DNA is expected to be low. In developing this protocol, several measures are taken to avoid or minimize the chances of false-positive results.

The entire PCR protocol should ideally be carried out in three locations that are physically separate from one another as follows.

Location 1: the clean reagent area, for preparing the reaction mix. All reagents other than the template DNA are stored here. Never take any DNA or regular lab coat in to this area. Use dedicated micropipets and tube racks.

Location 2: for preparing and storing the template DNA. This is the place where the template DNA is added to the vials. A PCR work station called the Template Tamer is recommended for this purpose. A dedicated pipet set, vial stand, and pipet tips with aerosol barriers must be used.

Location 3: for the analysis of the amplified material. Amplified DNA is the major potential source of contamination in PCR. This location therefore, must ideally be located far away from the other two. Analysis of PCR-amplified samples involves electrophoresis, blotting, and probing.

See APPENDIX $2 D$ for additional precautions that should be taken with PCR.

\section{Materials}

$10 \times$ reaction buffer without $\mathrm{MgCl}_{2}$ (Promega; supplied with the enzyme)

$25 \mathrm{mM} \mathrm{MgCl} 2$ (Promega; supplied with the enzyme)

$1 \mathrm{mM}$ dNTP mix (see recipe)

$2.5 \mu \mathrm{M}$ sense and antisense primer solutions (see recipe)

Paraffin wax (Aldrich)

$5 \mathrm{U} / \mu \mathrm{l} \mathrm{Taq}$ DNA polymerase (Promega)

Template DNA: lysates of serial cell dilutions (see Support Protocol 3) including positive DNA standards

0.65-ml thin-walled PCR vials (Diagnostic Concepts)

Clean razor blade

25-ml glass beaker

Heating block accommodating 0.65-ml PCR vials

Template Tamer PCR work station (Coy Laboratory Products)

Thermal cycler 
Set up vials with master mix

1. Prepare master mix as follows, multiplying the volume for each ingredient by the number of samples; prepare enough for one additional reaction per every ten needed to allow for pipetting error:

$3.0 \mu 110 \times$ reaction buffer

$3.6 \mu \mathrm{l} 25 \mathrm{mM} \mathrm{MgCl} 2$

$5.0 \mu 11 \mathrm{mM}$ dNTP mix

$5.0 \mu 12.5 \mu \mathrm{M}$ sense primer

$5.0 \mu 12.5 \mu \mathrm{M}$ antisense primer

$8.4 \mu \mathrm{M}$ sterile distilled water.

In the final $50 \mu \mathrm{l}$ reaction volume (see step 8) the concentrations of these ingredients will be $1 \times$ reaction buffer, $1.8 \mathrm{mM} \mathrm{MgCl}_{2}, 100 \mu \mathrm{M} 4 \mathrm{dNTP}$ mix, $250 \mathrm{nM}$ sense primer, and 250 $n M$ antisense primer.

2. Carefully deposit $30 \mu \mathrm{l}$ of the master mix at the bottom of each thin-walled PCR vial without letting the solution run down the wall.

The final $50 \mu l$ PCR reaction mix is assembled in three phases: $30 \mu$ master mix, then 10 $\mu l$ Taq DNA polymerase solution, then $10 \mu l$ DNA template. Note that Taq DNA polymerase must not be included in the master reaction mix so as to avoid nonspecific annealing and primer-dimer formation, as the enzyme is active at lower temperatures. Taq DNA polymerase is kept physically separate from the master mix with the help of a wax barrier as described below. See the Perkin-Elmer catalog for more information on this "hot-start" technique.

\section{Form wax barrier}

3. Cut the blocks of paraffin wax with a clean razor blade into small pieces. Drop one wax piece into a $25-\mathrm{ml}$ glass beaker. Set heating block to $\sim 100^{\circ} \mathrm{C}$, place the beaker on the block, and let the wax melt completely.

4. Quickly add 40 to $50 \mu \mathrm{l}$ of the molten wax (using a regular pipet tip) to each vial, along the wall just above the surface of the master mix in such a way that the solution is not disturbed but partially covered.

5. Remove the beaker and place the vials on the $\sim 100^{\circ} \mathrm{C}$ heating block. Remove the vials from the block as soon as the wax melts completely (which will take $\sim 1 \mathrm{~min}$ ). Let the vials cool down to room temperature.

The wax will solidify and make a physically hard barrier at the top of the master mix.

Perkin-Elmer sells wax beads that may be dropped one per vial. These beads, however, are extremely expensive. The simple alternative described here can achieve the same purpose very economically.

\section{Add Taq DNA polymerase}

6. Prepare the Taq DNA polymerase solution as follows, multiplying the volume for each ingredient by the number of samples:

$0.25 \mu 15 \mathrm{U} / \mu \mathrm{T}$ Taq DNA polymerase

$2.00 \mu 110 \times$ reaction buffer

$7.75 \mu \mathrm{l}$ sterile distilled water.

7. Place $10 \mu \mathrm{l}$ of the Taq DNA polymerase solution in the concave region of the wax layer above the master mix in each vial. Close the caps and transfer the vials to the Template Tamer PCR work station (location 2; see above).

The reaction components will come together only when the wax layer melts at elevated temperature $\left(>60^{\circ}\right.$ to $\left.65^{\circ} \mathrm{C}\right)$ as the PCR commences (i.e., during the first step of melting).

Delivery Systems for Gene Therapy

\subsubsection{3}

Supplement 12 
Oil overlay is not necessary as the wax itself can function as the vapor barrier.

Reaction components assembled as such may be stored for hours at $4^{\circ} \mathrm{C}$ before adding the template DNA.

\section{Add template DNA and perform PCR}

8. Add $10 \mu \mathrm{l}$ of each cell lysate (including positive DNA standards) to the appropriate vials. Close the caps and transfer vials to thermal cycler.

To add the DNA, immerse the pipet tip into the Taq DNA polymerase solution above the wax barrier and release; however, avoid piercing through the wax barrier. The most dilute clinical DNA should always be added first and the least dilute last. Similarly, later time-points should be added first and early time-points last. Do not bring the positive DNA standards to the Template Tamer until the addition of the DNA from the clinical samples is complete. This is important to avoid false-positive results.

Change gloves as frequently as possible, preferably between time points and dilutions.

\section{Amplify DNA}

9. Carry out PCR using the following thermal cycling conditions:

\begin{tabular}{|c|c|c|c|}
\hline Initial step: & $1 \mathrm{~min}$ & $94^{\circ} \mathrm{C}$ & $\begin{array}{l}\text { (ensures melting of } \\
\text { genomic DNA) }\end{array}$ \\
\hline \multirow[t]{2}{*}{36 to 40 cycles } & $45 \mathrm{sec}$ & $91^{\circ} \mathrm{C}$ & (denaturation) \\
\hline & $n \mathrm{sec}$ & $65^{\circ}$ to $72^{\circ} \mathrm{C}$ & $\begin{array}{l}\text { (annealing and extension; } \\
\text { see below) }\end{array}$ \\
\hline \multirow[t]{3}{*}{1 cycle: } & $10 \min$ & $72^{\circ} \mathrm{C}$ & (optional; see below) \\
\hline & $20 \mathrm{~min}$ & $99^{\circ} \mathrm{C}$ & (optional) \\
\hline & $10 \mathrm{~min}$ & $70^{\circ} \mathrm{C}$ & (optional) \\
\hline Final step: & indefinitely & $4^{\circ} \mathrm{C}$ & (hold). \\
\hline
\end{tabular}

The annealing temperature of a primer, which depends on the GC content and length of the primer, can be determined by the formula $T_{a}=4 X+2 Y-10^{\circ} \mathrm{C}$, where $X$ and $Y$ are the number of $A+T$ and $C+G$ residues, respectively. However, the optimal annealing temperature and the number of cycles required to detect a strong signal should be determined empirically. Provided the primers are 25 to 30 bp long and contain $40 \%$ to $50 \%$ GC, the annealing temperature will be in the range of $65^{\circ}$ to $72^{\circ} \mathrm{C}$.

The length of the extention period ( $n$ ) depends on the length of the DNA fragment amplified. Although this needs to be determined empirically, $1 \mathrm{~min} / \mathrm{kb}$ is often adequate.

The cycles following the annealing and extension are optional, as it often may be advantageous to inactivate the Taq DNA polymerase (at $99^{\circ} \mathrm{C}$ for $20 \mathrm{~min}$ ) following the PCR.

10. After the PCR, move the vials to the location reserved for DNA analysis (location 3; see above) and perform the necessary analyses.

The usual range of the PCR fragments amplified for diagnostic purposes is 200 to $600 \mathrm{bp}$. Often it may be possible to resolve PCR fragments of this size on a 1\% agarose gel (UNIT 2.7) and detect them by ethidium bromide staining. However, if the signal intensity is too low, it may be necessary to blot the DNA to a nitrocellulose membrane (UNIT 2.7) and hybridize with a radiolabeled (APPENDIX 3E) or nonisotopically labeled probe (e.g., UNITS4.3 \& 9.6).

Development of Molecular Genetic Interventions for HIV Infection

13.6.14 


\section{REAGENTS AND SOLUTIONS}

Use deionized, distilled water in all recipes and protocol steps. For common stock solutions, see APPENDIX 2; for suppliers, see SUPPLIERS APPENDIX.

\section{Borate buffer, pH 8.6}

$0.15 \mathrm{M}$ sodium borate

$0.15 \mathrm{M} \mathrm{NaCl}$

Adjust to $\mathrm{pH} 8.5$ with $1 \mathrm{M} \mathrm{NaOH}$

Store indefinitely at room temperature

dNTP mix, $1 \mathrm{mM}(10 \times)$

$10 \mu \mathrm{l} 100 \mathrm{mM}$ dATP

$10 \mu 1100 \mathrm{mM}$ dCTP

$10 \mu 1100 \mathrm{mM}$ dGTP

$6 \mu 1100 \mathrm{mM}$ dTTP

$4 \mu 1100 \mathrm{mM}$ dUTP

$960 \mu \mathrm{l} 10 \mathrm{mM}$ Tris.Cl, pH 8.0 (APPENDIX 2D)

All of the above dNTPs may be purchased from Boehringer Mannheim.

Do not use distilled water to dilute dNTPs as the low $\mathrm{pH}$ of water may cause depurination. $10 \mathrm{mM}$ Tris. Cl, $\mathrm{pH}$ 8.0, is preferable to TE buffer because the EDTA present in TE buffer may chelate the $\mathrm{Mg}^{2+}$ ions needed for PCR.

Presence of dUTP in the PCR reaction mix is important as a preventive measure to control false-positive results. If false-positive results are encountered as a result of carryover contamination, employing uracil-N-glycosylase $(U N G)$ in the PCR may help to overcome that problem. Refer to the Perkin-Elmer catalog for additional details.

The combined concentration of dTTP and dUTP should be equivalent to that of other dNTPs. Taq DNA polymerase has a higher affinity for dTTP. Under the PCR conditions used (see Support Protocol 4), approximately one dUTP will be incorporated into the amplified DNA for every 15 to 20 dTTPs. This rate of dUTP incorporation will not affect the efficiency of the amplification. The amplified DNA, on the other hand will be UNG-digestible.

\section{Quick lysis solution A}

$100.0 \mu 11 \mathrm{M} \mathrm{KCl}$ (APPENDIX 2D)

$10.0 \mu 11 \mathrm{M}$ Tris $\cdot \mathrm{Cl}, \mathrm{pH} 8.0($ APPENDIX $2 D)$

$2.5 \mu 11 \mathrm{M} \mathrm{MgCl}_{2}$ (APPENDIX 2D)

$887.5 \mu 1$ sterile distilled $\mathrm{H}_{2} \mathrm{O}$

Store up to 6 months at $22^{\circ} \mathrm{C}$

\section{Quick lysis solution B}

$10 \mu 11 \mathrm{M}$ Tris.Cl, $\mathrm{pH} 8.0$ (APPENDIX 2D)

$2.5 \mu 11 \mathrm{M} \mathrm{MgCl}_{2}$ (APPENDIX 2D)

$100 \mu 110 \%(\mathrm{v} / \mathrm{v})$ Tween 20

$100 \mu 110 \%(\mathrm{v} / \mathrm{v}) \mathrm{NP}-40$

$777.5 \mu 1$ sterile distilled $\mathrm{H}_{2} \mathrm{O}$

Store mixture of above components up to 6 months at $22^{\circ} \mathrm{C}$

Add $5 \mu \mathrm{l}$ proteinase $\mathrm{K}$ (from $10 \mathrm{mg} / \mathrm{ml}$ stock) immediately before use

\section{Primers}

Usually, primers are custom-made and supplied as dry pellets. Dissolve the pellet in $250 \mu \mathrm{l}$ of $10 \mathrm{mM}$ Tris. $\mathrm{Cl}, \mathrm{pH} 8.0$ (APPENDIX2D) and microcentrifuge $1 \mathrm{~min}$ at 10,000 $\mathrm{rpm}, 4^{\circ} \mathrm{C}$, to remove the suspended material, then transfer the solution to clean vials and store on ice. Dilute the primer solution 1000-fold and measure $\mathrm{OD}_{260}$ and $\mathrm{OD}_{280}$. The DNA concentration can be calculated using the formula: [DNA] $=\mathrm{OD}_{260} \times$ dilution factor $\times 33 \mathrm{mg} / \mathrm{ml}=\mathrm{OD}_{260} \times 1000 \times 33 \mathrm{mg} / \mathrm{ml}$. Dilute the primers with 
$10 \mathrm{mM}$ Tris. $\mathrm{Cl}, \mathrm{pH} 8.0$, to $2.5 \mu \mathrm{M}$. These will be the $10 \times$ primer stocks for PCR. Store in $250-$ or $500-\mu \mathrm{l}$ aliquots up to 6 months at $-20^{\circ} \mathrm{C}$. Avoid repeated freezings and thawings.

The concentration $(2.5 \mu \mathrm{M})$ of the primer stock is arrived at as follows. The average molecular weight of an oligonucleotide is equal to $n$ (the number of bases in the oligonucleotide) multiplied by the mean molecular weight of a base. If $n=25$, then the average molecular weight of an oligonucleotide $=25 \times 310 \mathrm{Da}=7750 \mathrm{Da}$. Therefore, $7.75 \mu \mathrm{g} / \mathrm{ml}=$ $1.0 \mu \mathrm{M}$ solution and $19.40 \mu \mathrm{g} / \mathrm{ml}=2.5 \mu \mathrm{M}$ solution (10× primer stock).

Additional purification of the primers is usually not necessary. If desirable, primers can be efficiently precipitated with $5 \mathrm{vol}$ of ethanol in the presence of $10 \mathrm{mM} \mathrm{MgCl}$. They are then washed once with $75 \%$ ethanol and dissolved in $10 \mathrm{mM} \mathrm{Tris.Cl,} \mathrm{pH} 8.0$.

\section{COMMENTARY}

\section{Background Information}

Although gene therapy is in its infancy, significant advances have been made during the past seven years both in vector design and technology. Many approaches for the treatment of HIV-1 have been suggested, but most fall into two general types of strategies. The first type of strategy ("intracellular immunization") is protein-based-e.g., employing transdominant negative proteins and intracellular antibodies that target essential viral proteins. The second type of strategy is RNA-based-e.g., employing RNA decoys, ribozymes and antisense molecules (reviewed in Nabel, 1994), which interfere with essential viral RNA-binding proteins or cleave/inactivate viral RNA. Two protocols, involving the transdominant negative Rev M10 protein (Nabel et al., 1994) and ribozymes (Leavitt et al., 1994) are presently in the clinical-trials and preclinical trials phase, respectively. Despite the numerous remaining questions surrounding the use of gene therapy for AIDS, the application of these techniques is based primarily on understanding of the molecular regulation of HIV replication and increasing sophistication of gene delivery systems. Because of the relative lack of success achieved with drug therapies and more traditional approaches to preventing and controlling AIDS, the continued development of innovative gene therapy studies and applications is a promising approach to the control of this devastating disease.

\section{Critical Parameters}

\section{Cell activation}

Because the procedures utilized to activate $\mathrm{T}$ cells may also activate any endogenous retrovirus present in infected cells in culture, antiretroviral agents should be included to inhibit virus replication and possible reinfection of permissive cells. The authors have found that the addition every 3 days during culture of 5 $\mu \mathrm{m}$ Delavirdine, a bis-heteroarylpiperazine (BHAP) compound, which is a non-nucleoside reverse transcriptase inhibitor, is sufficient to inhibit virus expression below the level of p24 antigen detection (as determined by Coulter p24 ELISA analysis over culture periods in the 7- to 14-day range). Other antiretrovirals may also be used, but should be tested for efficacy prior to use in the protocol. The antiviral agent must be specific for HIV and must not interfere with integration of the murine-derived retroviral vector used to transduce the cells. If cells are cultured for extended periods of time, the chance of generating drug-resistant virus strains is increased.

The methods employed to stimulate $\mathrm{T}$ cells ex vivo may have a profound effect on the subsequent survival potential upon reinfusion back into the patient, irrespective of the presence of any potential protective gene. Work by Levine et al. (1996) has strongly suggested that the method of stimulation indeed affects the susceptibility of $\mathrm{CD}^{+}$cells to HIV infection and influences the growth potential in vitro of the virus. The most effective method of stimulation was to incubate cells with Dynal magnetic beads conjugated with antibodies against both $\mathrm{CD} 3$ and CD28, followed by culture in the absence of exogenous IL-2. Stimulation with PHA/IL-2 and anti CD3/IL-2 were shown to increase the susceptibility to HIV infection as compared to $\mathrm{CD} 3 / \mathrm{CD} 28$ stimulation. It remains to be seen whether similar finding will be seen in vivo.

\section{Cell culture}

In regard to the type of medium to use, many commercially available media are available for expansion of PBL, the most commonly used being X-Vivo 15 (Bio-Whittaker) and AIM V Genetic HIV Infection 13.6.16 
(Life Technologies). The authors use X-Vivo 15 in the absence of serum; however many investigators grow the cells in X-Vivo medium in the presence of $5 \%$ human serum and $20 \mathrm{mM}$ HEPES. The authors have found that cells grow well in the absence of serum; furthermore the use of serum-free medium eliminates the testing and risks involved in using lots of pooled human serum.

\section{Transduction}

When considering whether to employ particle-mediated or retroviral transduction to introduce the "protective gene" into cells, many factors need to be considered. The extensive time and expenses incurred in producing and testing a retroviral vector/producer are very high in comparison to those involved in preparing and testing a plasmid for particle-mediated transfer. Also, the worry about the emergence of replication-competent viruses and their oncogenic potential is eliminated with nonviral delivery systems. Although transient gene expression can be very high with particle-mediated gene transfer, the persistence of expression and degree of DNA integration is not as wellstudied. Retroviruses may be so adapted by evolution for persistence and survival that the present plasmid vectors may not be as effective as retroviral vectors for long-term expression and engraftment. Although only two methods have been described for transduction of cells, other methods of transduction could equally be adapted to the general protocols if efficient gene transfer can be achieved by these techniques.

\section{Primer design}

Primer design is one of the most important factors in PCR sensitivity and specificity. Ideally, primers should lack any secondary structures and should not be complementary to each other. The GC content should be $40 \%$ to $50 \%$ and they should be 25-30 bp long. This would allow the primers to anneal at higher temperatures, enabling Taq DNA polymerase to function more efficiently. Furthermore, test and control vectors should be designed so that a single set of PCR primers can be used to distinguish the two on the basis of size.

\section{Anticipated Results}

The procedures involved in isolating, expanding, and transducing cells are relatively straightforward, and should be within the capability of competent experienced laboratory personnel.
Following reinfusion back into the patient, the relative chance of picking up the presence of transduced cells by PCR is dependent on many factors. Assuming that PCR analysis is well-optimized, that the transduction frequency is in the $1 \%$ to $10 \%$ range, and that the number of cells reinfused is $10^{10}$, the chance of picking up the signal immediately post-reinfusion is high. However the chance of detection at later time-points is dependent on the survival/replication of the transduced cells, their trafficking patterns, their lack of immunogenicity, and the immune condition and viral load of the patient. In an ideal situation, it would be hoped that the survival frequency of cells transduced with the protective gene would be higher than that of those cells transduced with a control nonprotective construct. In the author's gene therapy protocol, Rev M10transduced cells were detected in the patient by PCR following reinfusion when retroviral or particle-mediated gene delivery was employed (Woffendin et al., 1996 and unpublished data).

\section{Time Considerations}

The time required for activation and expansion of cultures is $\sim 1$ week. The time required for the actual transductions is dependent on the method employed. Retroviral transduction takes very little hands-on time, whereas particle-mediated transductions are fairly time-consuming-involving 4 to $6 \mathrm{hr}$ for the multiple transductions required for $10^{9}$ cells. The use of a hand-held device (Agracetus) for the shooting procedure should result in substantial savings in time during this part of the protocol. The initial steps involving separation of lymphocytes and selection of $\mathrm{CD}^{+}{ }^{+}$cells is quite laborintensive because of the large number of cells involved. However, once the transductions are completed, the time required for routine culture and expansion of cells should be only 1 to $2 \mathrm{hr}$ a day.

\section{Literature Cited}

Leavitt, M.C., Yu, M., Yamada, O., Kraus, G., Looney, G., Poeschla, E., Wong-Staal, F. 1994. Transfer of an anti-HIV-1 ribozyme gene into primary human lymphocytes. Hum. Gene Ther. 5(9):1115-1120.

Levine, L.L., Mosca, J.D., Riley, J.L., Carroll, R.G., Vahey, M.T., Jagodzinski, L.L., Wagner, K.F., Mayers, D.L., Burke, D.S., Weislow, O.S., St. Louis, D.C., and June, C.H. 1996. Antiviral effect and ex vivo CD4 T cell proliferation in HIV positive patients as a result of CD28 costimulation. Science 272: 1939-1943.
Delivery Systems for Gene Therapy

13.6.17 
Nabel G.J. Gene therapy approaches to AIDS. 1994. AIDS 8 (suppl. 1): S61-69.

Nabel, G.J., Fox B.A., Post L., Thompson, C.B., and Woffendin, C. 1994. A molecular genetic intervention for AIDS-effects of a transdominant negative form of Rev. Hum. Gene Ther. 5:79-92.

Poli, G. and Fauci, A.S. 1993. General guidelines for experimenting with HIV. In Current Protocols in Immunology (J.E. Coligan, A.M. Kruisbeek, D.H. Margulies, E.M. Shevach, and W. Strober, eds.) pp. 12.1.1-12.1.7. John Wiley \& Sons, New York.

Sanford, J.C., Smith, F. D., and Russell, J.A. 1993. Optimizing the biolistic process for different biological applications. Methods Enzymol. 217: 483-509.

Strober, W. 1996. Obtaining human peripheral blood cells. In Current Protocols in Immunology (J.E Coligan, A.M. Kruisbeek, D.H. Margulies, E.M. Shevach, and W. Strober, eds.) pp. A.3.13 A.3.14. John Wiley \& Sons, New York.
Woffendin, C., Yang, Z.Y., Ranga, U. , Xu, L., Yang, N.S., Sheehy, M.. J., and Nabel, G.J. 1994. Nonviral and viral delivery of HIV protective gene into primary T cells. Proc. Natl. Acad. Sci. U.S.A. 91:11581-11585.

Woffendin, C., Ranga, U., Yang, Z.Y., Xu L., and Nabel G.J. 1996. Expression of a protective gene prolongs survival of $\mathrm{T}$ cells in HIV infected patients. Proc. Natl. Acad. Sci. U.S.A. 93: 28892894.

Contributed by Clive Woffendin,

Udaykumar Ranga, and Gary J. Nabel University of Michigan Medical Center Ann Arbor, Michigan

Development

of Molecular

Genetic

Interventions for

HIV Infection

13.6.18

Supplement 12 